\title{
Efficacy of Microbial Consortia against Bacterial Wilt Caused by Ralstonia solanacearum in Hydroponically Grown Lettuce Plant
}

\author{
Parveen Khan*, Lohit Chandra Bora, P. K. Borah, Popy Bora and Kuldeep Talukdar
}

Department of Plant Pathology, Assam Agricultural University, Jorhat-785 013, India

*Corresponding author

\section{A B S T R A C T}

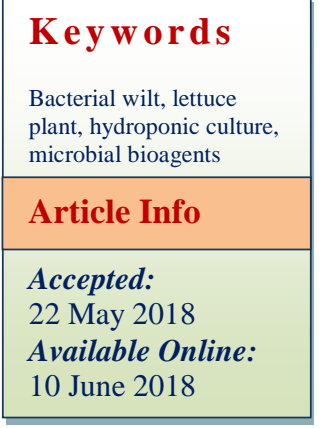

Efficacy of three potential microbial bioagents, viz. Trichoderma viride, Bacillus thuringiensis, Pseudomonas fluorescens were evaluated against bacterial wilt of lettuce under hydroponic culture system. The microbial bioagents were tested in vitro for their antagonistic properties against Ralstonia solanacearum, the causal agent of bacterial disease in lettuce. Bioagents applied alone or as consortia, significantly reduced bacterial wilt pathogen in vitro producing varying sizes of inhibition zones in TTC medium. The inhibition produced by the combination of three antagonists $T$. viride, B.thuringiensis and P. fluorescens was significantly highest (70.27\%) followed by combination of two bioagents $T$. viride and Bacillus thuringiensis $(63.83 \%)$. This was followed by $T$. viride and P. fluorescens $(59.84 \%)$. The combination of three antagonists $T$. viride, $B$. thuringiensis and $P$. fluorescens could also significantly reduce bacterial wilt incidence of lettuce plant in hydroponic culture tank

\section{Introduction}

Hydroponics or growing plants on mineral nutrient solutions without soil is a potential area in the agricultural development and economy for commercial food production and getting popularity all over the world. The advantage of hydroponic production was initially explored as an alternative to field production due to the ease of plant growth control and prevention of major disease causing agents known to overwinter in general soil environments (Stanghellini and Rasmussen, 1994). The system reduces the constant input costs and improves the economic efficiency of the fertigants, and also prevents environmental pollution such as contamination of sub-surface water sources
(Carruthers, 2002). Presently, hydroponic agriculture system has been successfully employed to grow various commercial and specialty crops including strawberries, tomatoes, peppers, leafy vegetables, eggplants, cucumbers and many more.

Lettuce (Lactuca sativa) is one of the vegetable crops, which is mostly cultivated hydroponic systems (Stanghellini and Rasmussen, 1994) either with or without artificial medium.Lettuce plants are susceptible to several air-borne and soil borne diseases, some of them e.g., - Pythium wilt and damping, Fusarium root rot, Rhizoctoniarot, lettuce drop (Sclerotinia minor), bacterial soft rot (Pectobacterium carotovorum) are more common. Some of 
these diseases have been detected in hydroponic cultures and are serious risk to lettuce production (Mercier and Manker, 2005). $R$. solanacearum (Rs), damages a wide range of crops grown in hydroponics (Hayward, 1995).The pathogen is of great concern in hydroponically grown tomatoes and cucurbits where it can devastate entire crops in minimal time due to the motile nature of the organism allowing cross infection between plants, as well as the environmental conditions being ideal for infection (Guo et al., 2004). Our finding related to association of Rswith hydroponic lettuce seems to be the first report from India with hydroponically grown lettuce.

It has been earlier reported that the bacterial pathogen spread to other plants is easier through contaminated surface water (Olsson, 1976). Since, these can be prevented by chemical based methods however nonchemical measures are most preferable over chemical methods in hydroponics due to environmental, food safety and health concerns. The Biological control involving antagonists and botanicals has been suggested to be ideally suited for closed structure of soilless systems. Biocontrol agents can easily be added to nutrient solutions in a hydroponic system and be dispersed (Paulitz, 1997). BCAs such as Pseudomonas spp., Bacillus spp., has been effective for their antibacterial activity against Rs (Ramesh et al., 2012). With this background the present study has been attempted to determine a sustainable management of Bacterial wilt disease in lettuce crop under hydroponic system through bio-intensive approach

\section{Materials and Methods}

The study was carried out in the laboratory and green shade net house of the Department of Plant Pathology, Assam Agricultural University, Jorhat, Assam, during 2016.

\section{Hydroponic cultivation}

Artificial hydroponic culture tanks (HCT) were made using plastics tubs (30 inch x 18 inch) to grow lettuce plant variety "Linda" following 'Static Solution technique' (Paulitz, 2001). Floating Styrofoam boards were used as grow tray to place the seedlings in the upper side of the HCT tank. Disposable plastic glasses $(7.5 \mathrm{~cm}$ diam.) filled with sterilized coco peat were used as growing media and to keep the lettuce plants upright. Modifications were made in such way that 90 per cent of the disposal glass planted with lettuce plant remained inside the hydroponic solution. Artificial aqua tank air pumps were connected with the HCT tank for continuous aeration.

As a source of micro and macro nutrients in required concentrations artificial nutrient solution (Flora series, General Hydroponics, France) was used following manufacturers guidelines. The nutrient rich HCT tank water was stirred at regular interval and the $\mathrm{pH}$ was adjusted to neutrality by adding dry $\mathrm{pH}$ down powder.

\section{Pathogen isolation}

For isolation the diseased lettuce plants were cut into thin pieces of one to two $\mathrm{cm}$ length. The pieces were surface sterilized with 1.0 per cent sodium hypochloride solution. Subsequently, the treated pieces were rinsed twice or thrice with sterilized water and were further cut into small bits of about $0.25 \mathrm{~cm}$ length and transferred to a test tube containing $10 \mathrm{ml}$ sterile distilled water. The bacteria were allowed to diffuse into the water by shaking the bits for $20 \mathrm{~min}$. From this stock solution, serial dilutions were made up to $10^{-6}$ level. Bacterial suspension of $0.1 \mathrm{ml}$ from the final dilution was pippetted aseptically to petriplates, containing $25 \mathrm{ml}$ of Triphenyl Tetrazolium Chloride (TTC) medium. The petriplates were then incubated at $28 \pm 2{ }^{\circ} \mathrm{C}$. 


\section{Microbial antagonists}

Three potentially aggressive antagonists, viz., Trichoderma viride (Tv), Pseudomonas fluorescens (Pf), Bacillus thuringiensis (Bt) were collected from the Biocontrol Laboratory of the Department of Plant Pathology, AAU, Jorhat. These were transferred to fresh medium and preserved at $4^{\circ} \mathrm{C}$ for evaluation study of their bioactive potential against Bacterial wilt pathogen. The cultures of fungal pathogen as well of all three antagonists $\mathrm{Tv}$, $\mathrm{Pf}$ and $\mathrm{Bt}$ were maintained throughout the period of study in PDA, Nutrient Agar and King's B (Himedia, Mumbai) media respectively, by routine sub-culturing at regular intervals and storing at $4^{\circ} \mathrm{C}$.

In vitro evaluation of antagonistic effect of different microbial bioagents against

TTC was taken as basal media to evaluate the inhibitory effects of bioagents in vitro conditions. Assay plates of Rs were prepared by seedling the bacterium in TTC. For these, $24 \mathrm{hr}$ growth of Rswas washed with sterile distilled water to prepare the stock culture of Rs. Serial dilution of stock bacterial suspension was made upto $10^{-8}$ level. From the final dilution $0.1 \mathrm{ml}$ aliquot was pipette asceptically to petriplates, each containing approximately $15 \mathrm{ml}$ TTC medium and allowed to solidify.

$0.5 \mathrm{~cm}$ diameter lawn of Pf, Bt grown in PDA was scooped out with the help of a sterilized cork borer containing cells of Pf and Bt and was transferred to the centre of TTC plates seeded earlier with cells of Rs. Following the same procedure $0.5 \mathrm{~cm}$ bit of fungal antagonist $\mathrm{Tv}$ grown in PDA plates was scooped out and transferred to the centre of TTC plates seeded earlier with cells of Rs. The plates were then incubated at $28 \pm 2^{\circ} \mathrm{C}$. The zone of inhibition produced was measured after 72 hours of dual inoculation. The data were converted to percentage of inhibition produced by the bioagents as compared to control.

\section{Preparation of microbe based bioformulation}

For preparation of microbe based bioformulation, the fungal and bacterial antagonists were at first multiplied individually in shake flasks using PD broth and nutrient broth respectively as growth medium. The flasks containing $200 \mathrm{ml}$ of respective medium were inoculated with $48 \mathrm{hr}$ old growth of Tv. The inoculum was prepared by pouring sterile water into slant culture of the fungus and subsequently shaking gently to lodge the vegetative parts into the suspension.

A loop of the inoculum suspension $\left(10^{8}\right.$ $\mathrm{cfu} / \mathrm{ml}$ ) was transferred to flasks containing PD broth. Similarly the bacterial antagonist Bt and $\mathrm{Pf}$ were multiplied in individual flasks. Inoculated flasks were incubated at $28+1{ }^{\circ} \mathrm{C}$ with orbital shaking at $150 \mathrm{rpm}$ for 72 and 48 hour for fungal and bacterial antagonists respectively. The consortia formulation was prepared by mixing individual broth culture of $\mathrm{Tv}, \mathrm{Bt}$ and $\mathrm{Pf}$ at a ratio of 1:1:1 after adjusting cell population to $10^{8} \mathrm{cfu} / \mathrm{ml}$ of each of the bioagent.

\section{In vivo evaluation of microbe based bioformulations based treatments}

The antagonists based formulations were applied to the nutrient solution before transplanting of lettuce seedling and as spray application after transplanting. After transplanting lettuce seedlings, the tanks were kept in net house to protect from direct exposure to sunlight. The observations recorded during experimentation were Disease incidence (\%); dry weight of the roots (g); dry weight of the shoots (g); height of the plant $(\mathrm{cm})$; yield/tank $(\mathrm{g})$. 


\section{Results and Discussion}

\section{Antagonistic effect of the bioagents against Ralstonia solanacearum}

The three compatible bioagents, viz., Tv, Bt, and Pf were tested against Rs singly and in consortia. The inhibition produced by the combination of three antagonists $\mathrm{Tv}, \mathrm{Bt}$, and Pf was significantly highest $(70.27 \%)$ followed by combination of two bioagents $\mathrm{Tv}$ and Bt63.83 percent. (Table 1). Murthy et al., (2013) reported that $\mathrm{Tv}$ possess antagonistic activity against bacterial wilt pathogen Rs in in vitro condition by excreting lytic enzymes such as $\beta 1,3$ - glucanases which can lyse the cell wall of the pathogen. The present observation of antagonism of $\mathrm{TV}$ against Rs might be as a result of similar type of mechanisms of parasitism. There are also reports that the fluorescent pseudomonads could antagonize plant pathogens by producing wide range of metabolites like antibiotics (Fravel, 1988), siderophores (Loper and Buyer, 1991) and other substances such as cyanide (Voisard et al., 1989). The antagonism by the bacterium and the antibiotic production indicates the involvement of deacetylphiorglucinol, pyrolnitrin and pyoluteorin in the natural antagonism between Pf and the pathogen (Lemessa and Zeller, 2007). The suppressive effect of Pf shown in our study against Rs might be due to production of similar type of metabolites.

Bt can inhibit growth of bacterial wilt pathogen Rs due to its rapid growth in broth culture, high thermal tolerance and formation of resistance spores (Broadbent et al., 1971). Some species of Bacillus suppress plant pathogens and insect pests by producing antibiotic metabolites, while others stimulate plant host defenses prior to pathogen infection (Van Loon, 2007). Formation of inhibition zone by the $\mathrm{Bt}$ is directly related to type of secondary metabolites produced by bacteria particularly in antibiosis, which acts against the target pathogens.

\section{Effect of microbe based bioformulations on lettuce disease incidence and yield attributing character in hydroponic tank}

The disease incidence caused by Rs in lettuce decreased significantly accompanied by significant increased in yield (gram/plant) when plants were treated with individual as well as consortia of different bioagents. Lowest disease incidence was exhibited by the bioformulation of consortia of $\mathrm{Tv}, \mathrm{Bt}$ and $\mathrm{Pf}$ $(18.57 \%)$ applied in nutrient solution as root treatment $(2.0 \%)$ and foliar spray $(1.0 \%)$ followed by the treatment with consortia of $\mathrm{TV}$ and $\mathrm{Bt}(30.75 \%)$. Plants treated with $B$. thuringiensis showed significantly higher disease incidence(73.14\%), however these were significantly lower as compared to control $(77.58 \%)$.(Table 2$)$

The significant decrease of bacterial wilt incidence and increase in lettuce yield in two best treatments, i.e., consortia of $\mathrm{Tv}, \mathrm{Bt}$, and Pfas well as consortia of $T$. viride and $B$. thuringiensis applied as combinations of root, foliar and water treatments might have occurred due to direct effects of the bioagents on suppression of the pathogen population in the plant rhizosphere. Earlier it was reported that Trichoderma sp. could significantly inhibit the growth of Rs in vitro and reduce bacterial wilt severity in tomato plants. Das (1999). Earlier similar observation was reported that Pf strain caused strong inhibition of Rs in in vitro assay plates and prevented root and plant infections ingrowth chambers as well as in soils naturally infected by the pathogen (Ciampi et al., 1996).

All the three microbial bioagents $\mathrm{Tv}, \mathrm{Bt}$, and Pf significantly improved the plant growth parameters as compared to the untreated control plant. 
Table.1 Suppressive effect different antagonist and their combination against $R$. solanacearum

\begin{tabular}{|c|c|c|c|}
\hline Treatment & Bioagents & $\begin{array}{l}\text { Radial growth } \\
(\mathbf{m m})\end{array}$ & Inhibition (\%) \\
\hline $\mathbf{T}_{0}$ & R. solanacearum (alone) & 0.00 & $\begin{array}{c}0.00 \\
(0.57)\end{array}$ \\
\hline$T_{1}$ & T. viride & 36.12 & $\begin{array}{c}39.24 \\
(38.76)^{*}\end{array}$ \\
\hline $\mathbf{T}_{2}$ & P. fluorescens & 24.65 & $\begin{array}{c}32.26 \\
(34.76)\end{array}$ \\
\hline $\mathbf{T}_{3}$ & B. thuringiensis & 55.20 & $\begin{array}{c}51.47 \\
(45.80)\end{array}$ \\
\hline $\mathbf{T}_{4}$ & T. viride $+P$. fluorescens & $43.25+23.92$ & $\begin{array}{c}59.84 \\
(50.65)\end{array}$ \\
\hline $\mathbf{T}_{5}$ & T. viride $+B$. thuringiensis & $39.80+23.92$ & $\begin{array}{c}63.83 \\
(53.01)\end{array}$ \\
\hline $\mathbf{T}_{6}$ & P. fluorescens $+B$. thuringiensis & $24.75+23.30$ & $\begin{array}{c}46.92 \\
(43.22)\end{array}$ \\
\hline $\mathbf{T}_{7}$ & $\begin{array}{l}\text { T. viride }+P . \text { fluorescens }+ \\
\text { B.thuringiensis }\end{array}$ & $32.00+25.25+22.00$ & $\begin{array}{c}70.27 \\
(56.91)\end{array}$ \\
\hline & S.Ed $( \pm)$ & & 1.91 \\
\hline & $\mathrm{CD}_{0.05}$ & & 3.31 \\
\hline
\end{tabular}

*Data in the parenthesis are angular transformed values

Table. 2 Effect of different microbe based formulation on bacterial wilt incidence caused by $R$. solanacearum and yield of hydroponically grown lettuce plant

\begin{tabular}{|c|c|c|c|c|}
\hline Treatment & $\begin{array}{c}\text { Disease } \\
\text { incidence } \\
(\%)\end{array}$ & $\begin{array}{c}\text { Disease } \\
\text { reduction } \\
(\%)\end{array}$ & $\begin{array}{l}\text { Yield } \\
\text { (g/plant) }\end{array}$ & $\begin{array}{c}\text { Yield } \\
\text { increased } \\
\text { over control }\end{array}$ \\
\hline $\mathrm{T}_{0}=$ Control & $\begin{array}{c}77.58 \\
(61.68)\end{array}$ & - & 27.25 & \\
\hline $\begin{array}{l}\mathrm{T}_{1}=T . \text { viride }+P . \text { fluorescens }+B \text {. } \\
\text { thuringiensis }\end{array}$ & $\begin{array}{c}18.57 \\
(25.48)\end{array}$ & 76.06 & 242.50 & 88.86 \\
\hline $\mathrm{T}_{2}=T$. viride $+B$. thuringiensis & $\begin{array}{c}30.75 \\
(33.65)\end{array}$ & 60.36 & 219.25 & 87.57 \\
\hline $\mathrm{T}_{3}=T$. viride $+P$. fluorescens & $\begin{array}{c}44.62 \\
(41.90)\end{array}$ & 42.48 & 183.75 & 85.17 \\
\hline $\mathbf{T}_{4}=B$. thuringiensis & $\begin{array}{c}73.14 \\
(58.76)\end{array}$ & 5.72 & 40.50 & 32.71 \\
\hline $\mathrm{T}_{5}=P$. fluorescens $+B$. thuringiensis & $\begin{array}{c}59.16 \\
(50.24)\end{array}$ & 23.74 & 75.00 & 63.66 \\
\hline $\mathrm{T}_{6}=T$. viride & $\begin{array}{c}46.21 \\
(39.93)\end{array}$ & 40.43 & 136.00 & 79.76 \\
\hline $\mathrm{T}_{7}=P$. fluorescens & $\begin{array}{c}65.67 \\
(54.03)\end{array}$ & 14.06 & 58.50 & 53.41 \\
\hline S. Ed ( $( \pm)$ & 2.29 & & 6.79 & \\
\hline $\mathrm{CD}_{0.05}$ & 3.91 & & 11.61 & \\
\hline
\end{tabular}

*Data in the parenthesis are angular transformed values 
Table.3 Effect of microbial bioformulations applied for management of Bacterial wilt on growth parameters of hydroponically grown lettuce plants

\begin{tabular}{|c|c|c|c|c|c|c|c|c|}
\hline \multirow[t]{2}{*}{ Treatments } & \multicolumn{8}{|c|}{ Growth characteristics } \\
\hline & $\begin{array}{c}\text { Shoot } \\
\text { length } \\
\text { (cm) }\end{array}$ & $\begin{array}{c}\text { Root } \\
\text { length } \\
(\mathrm{cm})\end{array}$ & $\begin{array}{l}\text { No of } \\
\text { leaves }\end{array}$ & $\begin{array}{l}\text { Shoot dry } \\
\text { weight } \\
\text { (g) }\end{array}$ & $\begin{array}{c}\text { Root dry } \\
\text { weight } \\
\text { (g) }\end{array}$ & $\begin{array}{l}\text { No of } \\
\text { roots }\end{array}$ & $\begin{array}{l}\text { Root fresh } \\
\text { weight } \\
\text { (g) }\end{array}$ & $\begin{array}{c}\text { Yield } \\
\text { (g/plant) }\end{array}$ \\
\hline $\mathrm{T}_{0}=$ Control & 5.87 & 2.25 & 4 & 0.36 & 0.23 & 10 & 1.82 & 27.25 \\
\hline $\mathrm{T}_{1}=T$. viride $+P$. fluorescens + B.thuringiensis & 34 & 27.75 & 22 & 16.41 & 5.62 & 54 & 27.12 & 242.50 \\
\hline $\mathrm{T}_{2}=T$. viride $+B$. thuringiensis & 27.00 & 22.50 & 18 & 13.75 & 4.20 & 50 & 23.37 & 219.25 \\
\hline $\mathrm{T}_{3}=T$. viride $+P$. fluorescens & 22.75 & 19.5 & 16 & 11.32 & 2.70 & 46 & 19.92 & 183.75 \\
\hline $\mathrm{T}_{4}=$ B.thuringiensis & 9.25 & 6.50 & 6.00 & 0.83 & 0.51 & 17 & 4.57 & 27.25 \\
\hline $\mathrm{T}_{5}=P$. fluorescens + B.thuringiensis & 15 & 10.75 & 9.00 & 5.83 & 0.87 & 30 & 11.4 & 75.00 \\
\hline $\mathrm{T}_{6}=T$. viride & 18.75 & 15.75 & 11 & 8.42 & 1.35 & 39 & 15.57 & 136.00 \\
\hline $\mathrm{T}_{7}=P$.fluorescens & 13.17 & 8.00 & 7.00 & 2.66 & 0.62 & 25 & 7.32 & 40.50 \\
\hline S. Ed ( \pm$)$ & 1.30 & 1.14 & 0.70 & 0.62 & 0.28 & 2.02 & & 6.79 \\
\hline $\mathrm{CD}_{0.05}$ & 2.22 & 1.96 & 1.20 & 1.06 & 0.48 & 3.46 & 1.51 & 11.61 \\
\hline
\end{tabular}




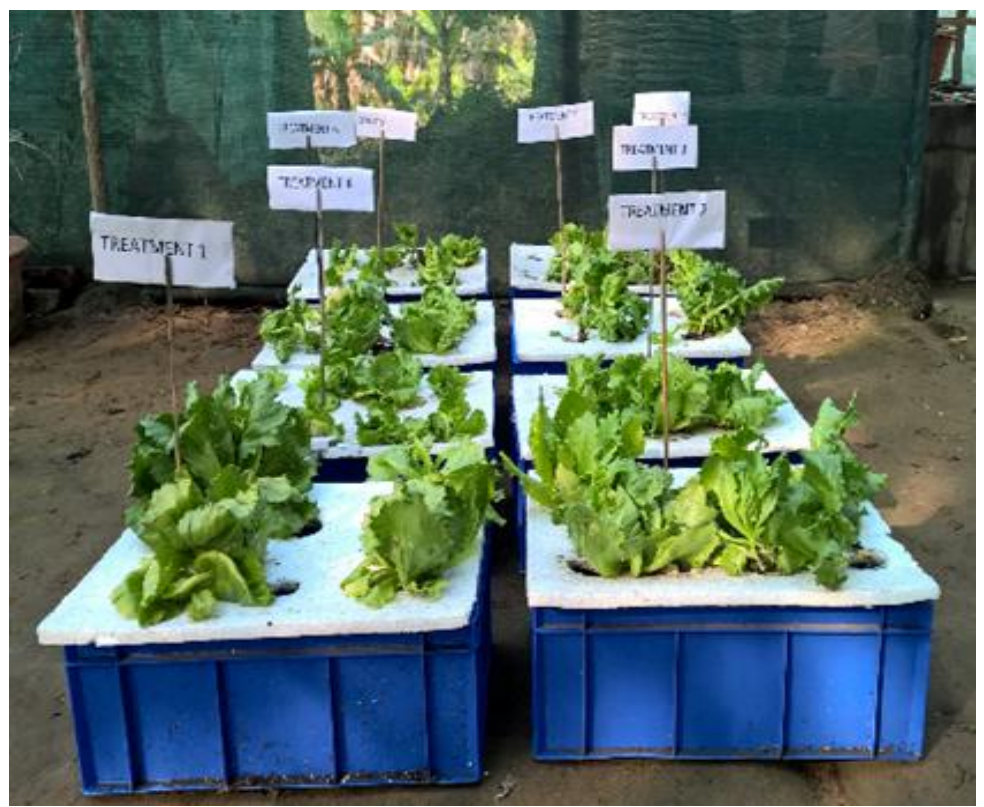

Plate.1 General view of experiments conducted in HCT

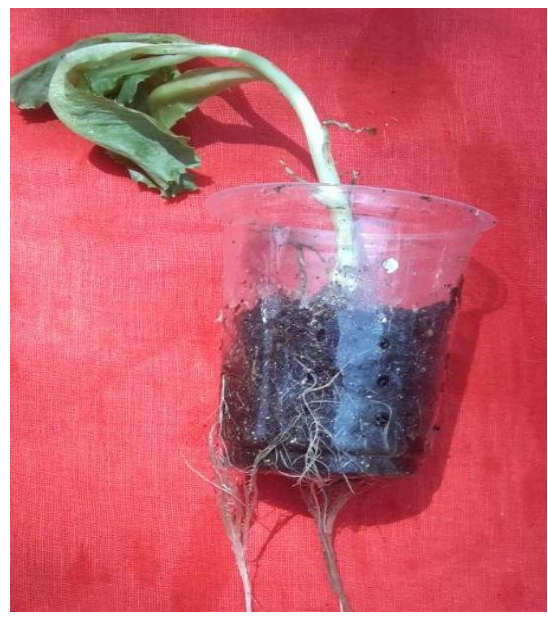

Plate.2 R.solanacearum infected plant

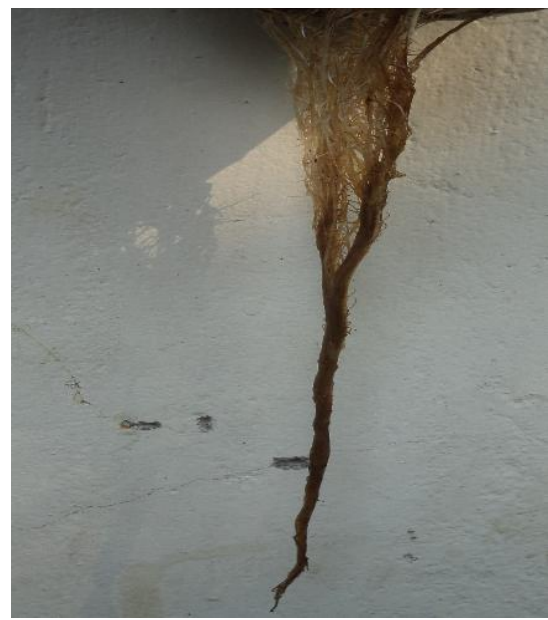

Plate.3 R.solanacearum infected root

Plate.4 Antagonism of different bioagents against $R$. solanacearum in vitro

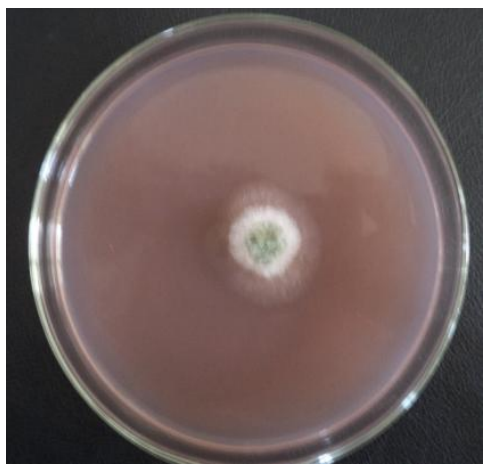

T. viride $+R$. solanacearum

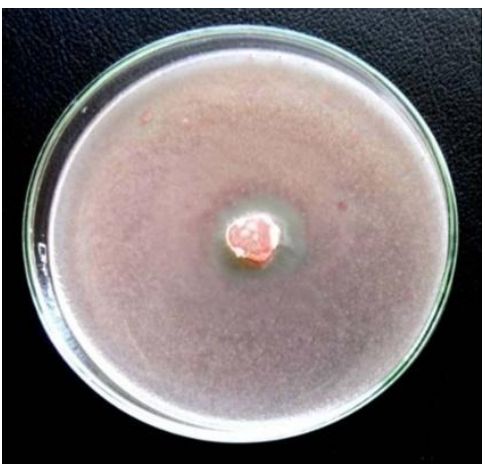

$P$. fluorescens $+R$. solanacearum

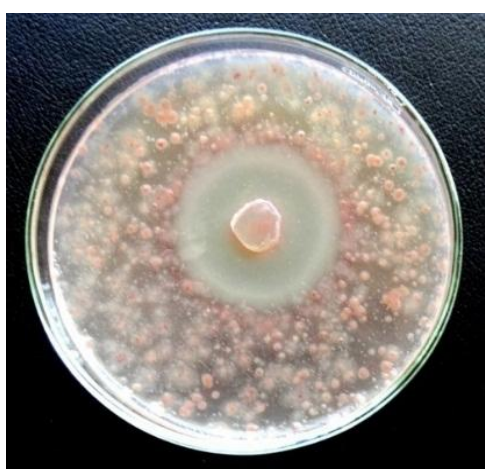

B. thuringiensis $+R$. solanacearum 


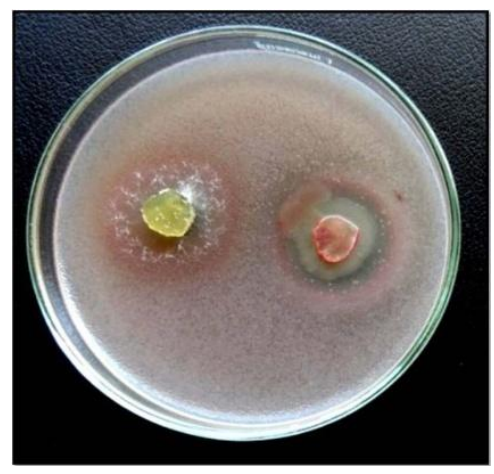

$T$. viride $+\boldsymbol{P}$. fluorescens $+R$. solanacearum

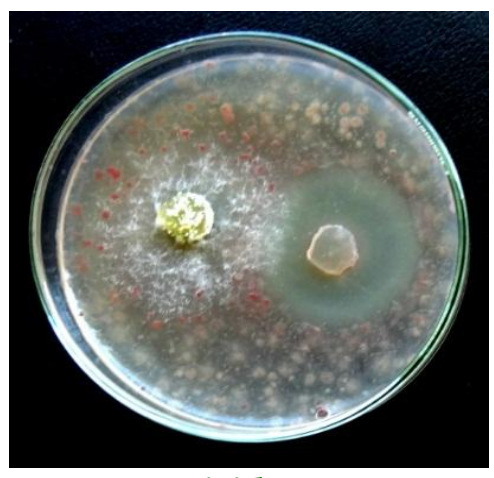

T. viride $+B$. thuringiensis $+R$. solanacearum

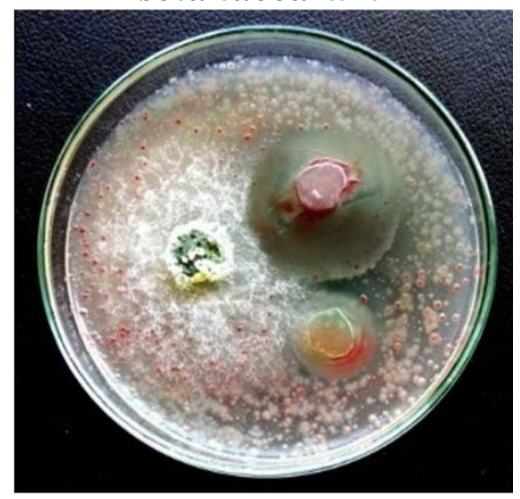

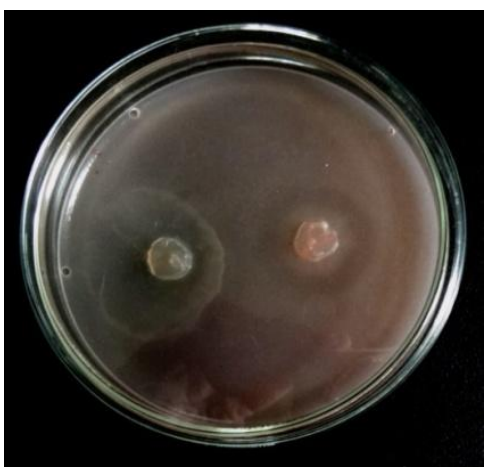

P. fluorescens +

B. thuringiensis $+R$. solanacearum

$T$. viride $+B$. thuringiensis $+P$. fluorescens $+R$. solanacearum

There was significant increase in root, shoot, no of leaves, no of roots and total biomass of lettuce plants in treatments where bioformulations of $\mathrm{Tv}, \mathrm{Bt}$, and $\mathrm{Pf}$ were applied as combination of root treatment $(2.0 \%)$ and foliar treatment $(1.0 \%)$. The highest shoot length $(34.00 \mathrm{~cm})$, root length $(27.75 \mathrm{~cm})$, no. of leaves (22), shoot dry weight $(16.41 \mathrm{gm})$, root dry weight (5.62 gm), no. of roots (54), root fresh weight (27.12 gm) was recorded when lettuce plants was treated with application of consortia bioformulation consortia of Tv, Bt, and Pf.(Table 4).

The yield of lettuce treated with consortia of different bioagents folowed similar trend as recorded for disease incidence. Highest yield was recovered from plants treated with bioformulation consortia of $\mathrm{Tv}, \mathrm{Bt}$, and $\mathrm{Pf}$ (242.50 g/plant) followed by plants treated with consortia of $T$. viride and $B$. thuringensis. The highest disease incidance and lowest yield of lettuce plantwas recorded in the control treatment, where no bioagent was applied (Table 3).

The increase in yield and decrease in disease incidence might be due to suppression of the pathogen due to application of bioagents. This finding is in agreement with Bustamanate et al., (1989). There was a negative correlation between yield and wilt incidence, which might be due to suppression of the pathogen population or exclusion of the pathogen from hydroponic lettuce niches by their enhanced antagonists activity (Mulya et al., 1996).

Earlier, similar type of observations have been documented by application of bioagent Trichoderma spp., Metarhizium spp. under greenhouse and field condition grown zinger (Deuri, 2013 and Bora et al., 2013). Kalita (1995) made similar observations of reduction in citrus canker incidence caused by 
Xanthomonas campestris pv. citri by application of $T$. viride.

Strains of $P$. fluorescens have been described as 'root colonizing bacteria' to indicate its potential to colonize the rhizosphere and rhizoplane (Weller, 1988). P. fluorescens have the ability to compete with other members of the soil microflora and also to produce antibiotics or induce a response in the host that favours growth of the biological control agents and inhibit the growth of the pathogen like $R$. solanacearum. Such mechanisms have been demonstrated by Bull (1987) and explained that the wheat take-all disease control by biological means was directly related to the rapid root colonization by antagonist like $P$. fluorescens. The present investigation might be due to similar type of mechanisms.

Similarly, results of Hyakumachi (2013) suggest that treatment of tomato roots with the cell-free filtrate of $B$. thuringiensis systemically suppressed bacterial wilt through systemic activation of the plant defence system. Treatment of tomato roots with $B$. thuringiensis culture followed by challenge inoculation with $R$. solanacearum suppressed the development of wilt symptoms to less than one third of the control. This finding suggests that $B$. thuringiensis can be a potential biocontrol agent for the suppression of plant diseases. This disease suppression in tomato plants was due to expression of defence-related genes such as PR-1, acidic chitinase, and $\beta$-1,3-glucanase. The phenomenon of suppression of $R$. solanacearum recorded in the present study could be correlated to similar types of mechanisms.

The application of $\mathrm{Tv}, \mathrm{Bt}$, and $\mathrm{Pf}$ based bioformulations as combination of foliar spray, root dip treatment can be a effective biocontrol option for management of bacterial wilt incidence of hydroponically grown lettuce plant. This study offers farmers to grow crops without the involvement of large expanses thus reducing high cost barrier for efficient crop production and the subsequent benefits can be achieved by farmers by using these bioformulation which is an alternative of high cost chemical fertilizer. Hydroponic culture could well dominate food production in the future as the North East India is abundantly rich in natural and naturally formed water bodies. These efforts, if successful will be a very good approach towards production of organic hydroponic cultured vegetables in Assam.

\section{Acknowledgements}

The authors are highly thankful to the Department of Plant Pathology and DBTAAU Centre, Assam Agricultural University, Jorhat, for providing facilities and financial assistance to carry out the studies.

\section{References}

Bora, L.C.; Deuri, D. and Kataky, L. 2013. RAPD analysis of ginger germplasms of North East India and assessment of their resistance against bacterial wilt disease caused by Ralstonia solanacearum. In: World Biodiversity Congress, Global Scientific Research Foundation, Chiang Mai and Rajabhat University, Chiang Mai, Thailand

Broadbent, P.; Baker, K.F. and Waterworth, Y. 1971.Bacteria and actinomycetes antagonistic to fungal root pathogens in Australian soils. Aust. J. Biol. Sci. 24: 925-944.

Bull, C.T. 1989. Wheat root colonization by disease suppressive bacteria and the effect of population size on severity of take-all caused by Gaeumannomyces graminis var. tritici M.S. Fleming Wesst State Univ. Pullman, pp. $75-81$

Bustamanate, G.P.; Ciampi-Panno, L. and Guaiquil, G.V. 1989. Inhibition in vitro of Pseudomonas solanacearum E.F. Smith using antagonistic strains of Pseudomonas 
fluorescens. Revista de. Microbiologia (Abstr.).

Carruthers, S. 2002. Hydroponics as an agricultural production system. Practical Hydroponics \& Greenhouses. Issue 63. (Mar/Apr), pp. 1-4.

Ciampi, P.L.; Fuentes, P.R.; Schoebitz, T.R. and Ortega, A.S. 1996. Biological control of Pseudomonas solanacearum, the bacterial wilt agent. I. Growth of Pseudomonas fluorescens strain BC8. Agro-Sur. 24(1): 3238.

Das, M. and Bora, L.C. 2000. Biological control of bacterial wilt of tomato caused by Ralstonia solanacearum. J. Agric. Sci. Soc. North-East India 13(1): 52-55.

Fravel, D. 1988. Role of antibiosis in the biocontrol of plant diseases. Ann. Rev. Phytopathol. 26: 75-91.

Guo, J.; Qi, H.; Guo, Y.; Ge, H.; Gong, L.; Zhang, L. and Sun, P. 2004. Biocontrol of tomato wilt by plant growth-promoting rhizobacteria. Biol. Control 29: 66-72.

Hayward, A.C. 2005. Research on bacterial wilt: A perspective on International linkages and Access to the literature. In: Bacterial Wilt Disease and the Ralstonia solanacearum Species Complex. Allen, C.; Prior, P. and Hayward, A.C. (eds.). The American Phytopathological Society, St. Paul, MN, pp. $1-8$.

Hyakumachi, M.; Nishimura, M.; Arakawa, T.; Asano, S.; Yoshida, S.; Tsushima, S. and Takahashi, H. 2013. Bacillus thuringiensis suppresses bacterial wilt disease caused by Ralstonia solanacearum with systemic induction of defense-related gene expression in Tomato. Microbes Environ. 28(1): 128-134.

Kalita, B.C. 1994. Epidemiology and management of bacterial wilt on tomato caused by Pseudomonas solanacearum E.F. Smith. M.Sc. (Agri.) Thesis, Assam Agric. Univ., Jorhat, Assam, India.
Lemessa, F. and Zeller, W.2007. Screening rhizobacteria for biological control of Ralstonia solanacearum in Ethiopia. Biol. Control 42: 336-344.

Loper, J.E. and Buyer, J.S. 1991. Siderophores in microbial interactions of plant surfaces. Mol. Plant-Microbe Interact.4: 5-13

Mercier, J. and Manker, D.C.2005. Biocontrol of soil-borne diseases and plant growth enhancement in greenhouse soil-less mix by the volatile-producing fungus Muscodor albus. Crop Prot. 25:355-362.

Mulya, K.; Wataneabe, M.; Goto, M.; Takikawa, Y. and Tsuyumu, S. 1996. Suppression of bacterial wilt disease of tomato by root dipping with P.fluorescens pfg32. Ann. Phytopathol. Soc. Japan62: 134-140

Murthy, F.U. and Srinivas, C. 2013. Induction of systemic resistance by Trichoderma asperellum against bacterial wilt of tomato caused by Ralstonia solanacearum. Int. J. Adv. Res. 1(10): 181-194.

Olsson, K. 1976. Experience of brown rot caused by Pseudomonas solanacearum in Sweeden. Bull. OPPE 6: 199-207

Paulitz, T.C. 1997. Biological control of root pathogens in soilless and hydroponic systems. Hort. Sci.32: 193-197.

Ramesh, R. and Phadke, G.S. 2012. Rhizosphere and endophytic bacteria for the suppression of eggplant wilt caused by Ralstonia solanacearum. Crop Prot.37: 35-41.

Stanghellini, M.E. and Rasmussen, S.L. 1994. Hydroponics: A solution for zoosporic pathogens. Plant Dis. 78: 1129-1138

Van Loon 2007. Plant responses to plant growthpromoting rhizobacteria. Eur. J. Plant Pathol. 119: 243-254.

Weller, D.M. 1988. Biological control of soilborne plant pathogens in the rhizosphere with bacteria. Ann. Rev. Phytopathol. 26: 379-407.

\section{How to cite this article:}

Parveen Khan, Lohit Chandra Bora, P. K. Borah, Popy Bora and Kuldeep Talukdar. 2018. Efficacy of Microbial Consortia against Bacterial Wilt Caused by Ralstonia solanacearum in Hydroponically Grown Lettuce Plant. Int.J.Curr.Microbiol.App.Sci. 7(06): 3046-3055. doi: https://doi.org/10.20546/ijcmas.2018.706.358 